\title{
Awqāf: Social Spending, Development Strategy and Financing
}

\author{
Volker Nienhaus \\ Former President University of Marburg Germany \\ and Visiting Professor University of Reading, UK
}

\begin{abstract}
A revitalization and development of old awqāf could generate notable revenues to finance social expenditures (although probably less than very optimistic estimates suggest). Awq $\bar{a} f$ should be conceived as institutions of the civil society, but they are actually managed by ministries or state agencies in most Muslim jurisdictions. Decisions on comprehensive awqāf development schemes should be made in a participatory setting that is compatible with the geographical coverage of waqf-based social benefits and gives $a w q \bar{a} f$ beneficiaries an organized voice. The financing of revitalization projects can be supported by cash $a w q \bar{a} f$ that can attract funds from people of all means. Further resources could be mobilized if figh and awq $\bar{a} f$ laws accept usufructs and financial rights as the basis for a waqf.
\end{abstract}

Keywords: Development strategy of $a w q \bar{a} f$, Social welfare schemes, waqf of rights

KAUJIE Classification: E22

\section{Awqā $f$ as a Substitute for or Supplement to Social Spending by the State?}

For Syed Khalid Rashid (2018) awqāf are "a welcome alternative to the state providing social welfare schemes which have dwindled down to insignificance, particularly in the Third World countries" (p. 54). Unfortunately, social welfare expenditures are seemingly the lowest in the poorest Muslim countries. Comparable data are only available for public health expenditures which, however, are a major if not the largest cate-gory of public social spending and hence, a reasonable proxy for total social spending $^{(1)}$. That state social welfare schemes dwindled to insignificance may be true for some Muslim majority countries, but certainly not for all. For example, the public social spending in Turkey more than doubled over the last 25 years from 5.5\% to $13.5 \%$ of GDP which is a significant dimension (although well below the OECD average of $21 \%$ of the GDP) ${ }^{(2)}$. It is doubtful whether the income from

(1) For data see SESRIC's OICStat database, http://sesric.org/oicstat.php.

(2) The OECD provides details on social and welfare issues, including a social expenditure database (SOCX), on its 
awq $\bar{a} f$ could come close to this dimension in the foreseeable future. There are (rough) calculations of the economic importance of $a w q \bar{a} f$ in the pre-modern time, but a systematic assessment of the current income potential is not avail-able. For example, in the

Republic of Turkey in 1923 three quarters of the country's arable land belonged to $a w q \bar{a} f$ and it is said that at one time 70 per cent of land in Delhi was owned by awqāf . . Historians indicate that more than one-third of agricultural land, and often up to half buildings in major cities in Syria, Turkey, Egypt, Morocco, Algeria, Iraq, and Palestine were $a w q \bar{a} f$ properties prior to those changes. This large share of the economy has been reduced to a relatively nominal amount. (Stibbard, Russell, \& Bromley, 2012, p. 796)

Rashid (2018) expects that out of at least 1.5 million $a w q \bar{a} f$ in existence (excluding mosques, graveyards, etc.) "not less than 25-30 thousand may be worth developing. These may produce hundreds of millions every year for welfare schemes" (p. 55).

To put this into perspective: the aggregate GDP of the 57 OIC members was $6,425,000$ million USD (2016), and they spent $2.7 \%$ of the GDP (2014) on health which amounts to roughly 175,000 million USD. "Hundreds of millions" would be more than enough to cover these expenses. How "hundreds of millions" have been calculated is not explained. A table with extraordinary growth rates of the income of $a w q \bar{a} f$ in India after their development is presented by S. K. Rashid, and it may be that such growth rates have influenced the estimation of the income generating power of developed $a w q \bar{a} f$ in general. However, the management of $a w q \bar{a} f$ in India may have been exceptionally poor so that the achieved improvements are untypically large. In countries where the awqa $\bar{f}$ management is better, development efforts may yield lower additional returns. Fractional evidence suggests that "hundreds of millions" is a very optimistic estimate. For Malaysia, the value of land under waqf properties was estimated at RM 1,177 million for 2014 which is equivalent to USD 336.8

website: http://www.oecd.org/social/. Public social spending includes public outlay on old-age and survivors pensions (not including the private contributions to pension the systems), health, family supports, incapacity-related benefits (disability and sickness payments), labor market policies, housing, and other social policy contingencies. million (exchange rate for end-2014). Assuming a possible annual return of $25 \%$, the income from this land would be USD 84.2 million. At a GDP of USD 338,073 million, this income amounts to only $0.02 \%$ of GDP. For Kuwait, the annual cash flow from the rent of waqf properties was KD 18 million (no year given). This is equivalent to $0.1 \%$ of the 2004 GDP or $0.04 \%$ of the 2014 GDP. The dimension of returns from financial investments of waqf resources is not reported (Abdel-Mohsin, 2016, p. 62, 162; GDP data from OICStat). For Bangladesh it is estimated that the proper development of waqf properties could generate an income of at least one hundred million taka a year. TK 100 million are $0.003 \%$ of the 2004 GDP (Ahmad \& Karim, 2017; GDP data from OICStat).

Furthermore, a massive awqāf development that should increase the awqāf income by 'hundreds of millions' would have a number of problematic side effects. For example, previously unproductive waqf land in prime locations could be converted into shopping centers with high rental returns. However, if the purchasing power of the consumers shopping in the new centers has not increased, they must have reduced their spending in other locations which, in turn, puts rentals there under pressure. The sum of the rental income generated by the old and new shopping centers would remain the same, only the shares of operators will change. The gain for a waqf-based new center comes at a loss for the older commercial centers.

As many $a w q \bar{a} f$ capable of development are underutilized plots of land in locations where rents for commercial or residential use are high, the development of several $a w q \bar{a} f$ at the same time in the same area would lead to a notable additional demand for the construction industry. Assuming that this industry does not have much idle capacities, the effect will be an increase in prices with a negative impact on other property developments. The financing of the waqf development by Islamic banks has a similar effect: unless the banks attract additional funds, their available resources will be redirected towards the awq $\bar{a} f$ development. Other "borrowers" will have to pay higher prices, and with higher financing costs some projects are no longer profitable and will be given up. 
A massive $a w q \bar{a} f$ development in an economy with a reasonable level of employment of all relevant factors of production (e.g. human resources and machinery in the construction industry, bank deposits for medium to long term real estate financing) will compress profits in the private sector and generate profits in the $a w q \bar{a} f$ sector. If profits shift from the private to the awq $\bar{a} f$ sector, the state would lose revenues from profit-related corporate taxes if awqāf profits were tax exempt. Nevertheless, the sum of money for social welfare expenditures will increase because $100 \%$ of the awqa $\bar{a} f$ profits will go there while lost taxes (which might have gone there) are only a percentage (e.g. $25 \%$ ) of the forgone profits.

\section{Sequencing and Selection: An Awqä $f$ Development Plan}

It is neither technically possible nor conceptually advisable to make efforts to revitalize 25-30 thousand $a w q \bar{a} f$ at the same time. A sequencing is required, and the question is: who shall determine the sequence of the awqāf (re)development and on the basis of what criteria? As the management of $a w q \bar{a} f$ has been taken over by the government (e.g. through a special ministry of $a w q \bar{a} f$ ) in most modern Muslim states, the authority for such decision would rest with the government by default.

The government can follow very different approaches for drawing up a development strategy for the $a w q \bar{a} f$ under its management. A basic assumption is that only a limited number of waqf development projects can be realized per year, and the first issue is to determine a reasonable selection criteria.

One strategy would be to give priority to the development of $a w q \bar{a} f$ that were established with a broadly defined class of beneficiaries and no explicit geographic stipulations or $a w q \bar{a} f$ with narrowly defined specific purposes which have become obsolete so that the waqf proceeds can now serve the poor and destitute in general. In both cases, the government would have the widest possible discretion to allocate awqāf income to social welfare projects. Such a strategy may work for some time, but it has some constraints. The number of $a w q \bar{a} f$ that meet the selection criteria is limited. Projects selected by these criteria may have only modest income generating capacities and low rates of return (with resulting difficulties to finance necessary investments). Furthermore, such a policy would change the character and/or perception of $a w q \bar{a} f$ from autonomous pro-viders of social welfare services to a source of revenues for public social spending of the state. This would hardly motivate people to establish new $a w q \bar{a} f$.

Another strategy may focus on performance and economic criteria such as the power of a waqf to generate income for the social purpose as mandated in the waqf deed. However, there are some peculiarities of $a w q \bar{a} f$ that could make such an approach less appealing on closer inspection. Many if not most $a w q \bar{a} f$ did not have the characteristics of "national" public goods accessible and available to all citizens irrespective of their location, status, profession, etc.; instead, $a w q \bar{a} f$ had a community orientation. Awqāf were typically established for beneficiaries who were members of a community that was mostly determined by personal and geographic criteria, e.g. people (such as orphans, sick, disabled, poor, etc.) who live in a particular neighborhood (village, city, region. etc.). A geographic focus might explicitly be mentioned in the waqf deed, or it could be implied by the limited outreach of the services provided by the waqf. Guild waqfs were set up by and for communities of artisans of a particular trade (such as tailors or weavers), and the membership was restricted to residents of one city (see, Hanna, 2011). Hence, each waqf represents a specific combination of purpose and geography. This has to be taken into consideration when decisions about the sequence of waqf development are taken.

A variant of this approach could be the selection of those $a w q \bar{a} f$ that show 'best in class' performance. Their strengthening by investments in their further development would not only improve social welfare services but could also generate role models. The problem with this idea is the lack of generally accepted performance criteria for $a w q \bar{a} f$ (on performance measures for $a w q \bar{a} f$ with reference to the specificities of the Malaysia awqāf system see, Arshad, Zain, Urus, \& Chakir, 2018).

A plausible criterion for a ranking of development projects could be their internal rate of return or return on investment. But this criterion may imply a strong bias towards $a w q \bar{a} f$ projects in a few cities with the highest real estate prices. A high concentration of the national waqf development on one or two cities may provoke a strong political opposition, especially if the 
benefits of the $a w q \bar{a} f$ are confined to communities in the cities. Therefore, the government may decide to distribute waqf development projects more evenly throughout the country. If for a given location or region several options with different types of beneficiaries are available, probably not all potential beneficiaries can be satisfied. This, again, may trigger political opposition. A government that depends on votes may prefer development projects that have the potential to maximize the number of votes in the next election. But a vote maximizing policy may not be appropriate from an economic point of view, and so on. In short, there are many intertwined conflicts and inefficiencies if the national government makes discretionary decisions on the sequencing of waqf development projects. There may be better institutional arrangements for such decisions.

A better arrangement should reduce the political quarrels and enhance the public acceptance of a sequenced development strategy for $a w q \bar{a} f$. This could be achieved by decision making (or at least decision advice) in a distinct body that is composed of representatives of the state and representatives of $a w q \bar{a} f$ beneficiaries. As social services provided by awqā $f$ often have a limited geographic impact, the structure of the body should allow for regional differentiations.

The beneficiaries are the "beneficial owners" of the social services facilitated by a waqf; therefore, it would be appropriate to give them a voice through organized procedures when decisions of fundamental importance for the future of "their" waqf are due. However, "the beneficiaries" is not a definitive list of individuals but an amorphous and mutable group of people whose voice should be articulated by proxies who are familiar with the impact of the social services facilitated by the waqf and with the overall social fabric and economic conditions in the affected geography. Most states have implemented schemes for political decision making or consultation with civic participation for different issues on various geographic levels such as provinces, regions, urban agglomerations, rural areas, cities, etc. Governments can choose from a wide variety of models and adapt them for a participatory body for decisions on $a w q \bar{a} f$ development. Municipalities as administrative units with certain self-government rights might be a good starting point. The integration of organizations of the civil society into a body for $a w q \bar{a} f$ development planning shall add competence to the process and consent and legitimacy to the outcome. The state/ government may reduce its dominance and accept organizations of the civil society as partners in waqf development planning, but it may remain the dominant player for two reasons.

First, the state has made significant material contributions to the $a w q \bar{a} f$ system over a long period of time. The $a w q \bar{a} f$ system is sometimes portrayed as if it was based (only) on charitable ${ }^{(3)}$ donations of wealth that pious Muslims had earned through successful businesses in the private sector.

\begin{abstract}
Indeed, economists looking at the waqf system would be perplexed by the fact that a myriad of essential services such as health, education, municipal, etc., were provided in history at no cost whatsoever to the government... providing the most essential social services without any cost to the government... [P]rivately accumulated capital may be voluntarily endo-wed to finance all sorts of social services to the society. (Cizakca, 1998, pp. 44-45).
\end{abstract}

Although this description seems to be reasonably correct for the largest number of $a w q \bar{a} f^{(4)}$, it grossly understates the importance of the state for the awqā $f$ system in terms of financial contributions. Over centuries, the largest $a w q \bar{a} f$ were donations by rulers and their entourage. Legally these $a w q \bar{a} f$ were based on the donation of private wealth, but factually state land was often used to create waqfs. For this purpose, land titles were given to the ruler and other state officials by which state land became private property that could be donated as a waqf. Furthermore, the wealth that was transferred by members of the ruling elite were rarely accumulated profits of private businesses; instead, more often (and particularly during the periods of territorial expansion) the transferred wealth was war booty allocated to members of the ruling elite, in particular to (successful) military comman-

(3) It is noteworthy that the concept of charity in Islam includes care for own family while the Western concept restricts charity to acts for the benefit of persons outside own family. Beneficial acts for family members as well as for unrelated persons bring the founder of a waqf closer to Allah (Stibbard et al., 2012, p. 786).

(4) It is widely recognized that religious motives were often commingled with more mundane motives such as the protection of wealth against confiscation or the avoidance of the Qur'ānic rules of inheritance. 
ders. This source of wealth for waqf creation is no longer available (Hoexter, 2002, p. 121, 124).

For example,

[i]n the Ottoman Empire only 1-2 per cent of $a w q \bar{a} f$ [were] set up by sultans with the rest being endowed by private individuals. Of these, 43 per cent were ordinary citizens and 57 per cent were members of the elite. (Stibbard et al., 2012, p. 796)

These percentages are in terms of the number of $w a q f s$, not their asset value. The asset value of awqāf created by sultans were much larger than 1-2 per cent. In Mamluk Cairo (13th-16th century), awqāf were established primarily by the military elite while $w a q f$ deeds of merchants were completely lacking see (Ghazaleh, 2011, p. 8).

Second, social welfare expenses from the state budget and social welfare services provided through $a w q \bar{a} f$ should be coordinated in such a way that their complementarity becomes transparent. It should become apparent that the development strategy for $a w q \bar{a} f$ follows its own logic and is not reduced to a filler for gaps in the social budget. It should also demonstrate the efforts of the state to create a conducive environment for the development of an autonomous $a w q \bar{a} f$ sector sustained by the civil society.

\section{Exemption from taxes and Financing of Awqäf Development}

It is often claimed that a component of a conducive environment for $a w q \bar{a} f$ is an exemption from taxes, particularly income and corporate taxes ${ }^{(5)}$. An exemption from indirect taxes respectively excise duties for $a w q \bar{a} f$ that generate income by similar activities as corporates gives the awqāf advantages over corporates that distort competitive markets. This is generally not advisable. An exemption from direct taxes (corporate taxes) which are usually levied on profits can be justified by the assignment of the waqf profits to social benefits. In a family waqf, the profits can be transferred to family members of the founder who can receive payments from the waqf that are by the amount of saved corporate taxes higher than what they could receive if the same business would be run as a family-owned corporate instead of a family

(5) A waqf could be exposed to corporate tax particularly in jurisdictions where it has a legal personality similar to that of a corporate. waq $f^{(6)}$. This advantage depends on the corporate tax rate and would be in many countries in a range of $20 \%$ to $30 \%$. If this is seen as an unfair advantage, family waqf could be excluded from the tax exemption for waqf.

Tax benefits can support the development of $a w q \bar{a} f$, but they are not effective if a waqf is dilapidated to such a degree that it has lost its capacity to generate an income. For such cases, but also for major development projects of revenue generating $a w q \bar{a} f$, external funds have to be mobilized. With a growing sophistication of the Islamic finance industry in general and Sharíah compliant project financing techniques in particular, new concepts have been introduced to the waqf development financing. Substantial amounts can be mobilized for $a w q \bar{a} f$ development from profit-seeking investors through techniques like build-operate-transfer, build-lease-sale, and build-transfer-operate (for surveys with cases see Obaidullah, 2013; World Bank, 2017; for a summary of innovative modes of financing waqf properties and 95 cases in 11 countries see Abdel-Mohsin, 2016, pp. 242-255). It is highly probable that more capital market instruments such as sukūk for $a w q \bar{a} f$ development will enrich the toolboxes of waqf managers who have to finance projects of large size.

On the other end of the spectrum, the awqāf authorities in some jurisdictions (e.g. in Malaysia) have extended the options for persons of small means to enjoy the religious benefits of a waqf by participation in cash waqfs. To become a wäqif, many people transfer small amounts of money to a trust fund that is managed, for example, by an Islamic bank. The aggregate money will constitute a new waqf. It can either be invested in a new project in the real economy or added to an existing waqf. The returns from the investment of the cash waqf resources shall be used for the financing of social benefits. The cash waqf can also contribute to the financing of the development of a dilapidated waqf (by increasing its capital). It can play the role of a "feeder waqf" for the old waqf, and it will participate in the returns that shall be boosted by the revitalization measures.

New techniques made the transfer of money to the trust fund more comfortable. At the beginning, cash was collected in mosques. Then paper-based and

(6) These payments should be subject to the income tax of the recipient. 
electronic bank transfer and card payments were introduced as well as regular deductions and transfers of small amounts from monthly salaries. Besides this technical progress, conceptual innovations have been introduced for the creation of cash waqfs such as "waqf shares" to finance the development of old waqfs. The modus operandi (of waqf shares) is as follows:

1. Waqf institutions issue shares to finance the execution of a project.

2. Individuals or corporations buy the shares and get an ownership certificate.

3. The waqf institution executes the project.

4. The return of the project will be channeled to the specified beneficiaries. (Abdel-Mohsin, 2016, p. 250)

The shares are sold in affordable denominations, and the shareholders do not receive any returns.

With the growing popularity of FinTech, more technological and conceptual innovations for cash waqfs will emerge. A first model for fund raising through an initial coin offering (ICO) is mentioned in Rashid's contribution (Rashid, 2018), but the conceptual added value of the proposed coin model does not become clear, and safeguards for consumer protection (especially against Sharī'ah non-compliance risks) deserves more attention.

At least from the literature (and the many reports on quite recent development projects for old $a w q \bar{a} f$ ), one gets the impression that a further growth of development activities can be expected. This would also increase the demand for feeder $a w q \bar{a} f$. Their potential for feeder $a w q \bar{a} f$ could be enhanced substantially if the list of acceptable "movable assets" for the creation of a waqf would be widened. In modern service economies, the economic significance of arable land is greatly diminished while the value of intangible assets such as intellectual property rights has multiplied. If intangibles like rights could be the used as assets for the creation of a "cash" waqf, the potentials (at least for "feeder waqfs" linked up with existing land-based waqfs) would also be multiplied.

For centuries, Islamic jurists (except for the Mālikīs) required the perpetuity of waqf assets, and in the last instance only land was considered perpetual. The traditional view that land is perpetual can be challenged in times of climate change with good arguments. People living on flat islands or in coastal areas exposed to regular typhoons and rising sea levels face a "physical temporality" of their land. But land cannot only be washed away, it can also dry up and become a barren desert. A plot of land can remain at the same location but lose its economic value. If there is, in principle, an "economic temporality" of land, then the fundamental difference between land and all other assets fades away. If all assets have limited economic life spans, perpetuity is a meaningful concept only in relation to the economic life of an asset. Perpetuity then means the full life span while temporality means a time shorter than the full life span. With that understanding, every asset can be donated for waqf in perpetuity.

The arguments of classical jurists have been sumarized in S.K. Rashid's contribution, and his conclusion is that "perpetuity of waqf which started as being nearly mandatory became, during the course of history, voluntary... As the law of waqf is nearly totally jurist made, it is logically open to amendments" (p. 63). Such amendments seem necessary in a world where economic perpetuity has ceased to exist. The conclusion is that the door should be open for acceptance of $a w q \bar{a} f$ built on rights.

This, however, does not mean that "anything goes". It is reported that during the $17^{\text {th }}$ century, rights pertaining to property became fully commoditized, i.e. they were treated and traded as commodities on their own decoupled from the underlying real asset.

[T] his period witnessed the development of many compatible forms of property ownership and use. For instance, a plot of land in the heart of al-Qahira could belong to one person or institution (say, a waqf established during the Mamluk period); that land might then be rented out to an individual, who in turn transformed the rent contract into a waqf; buildings might be constructed on the endowed land, and then made into an additional separate waqf; and so on. ... The availability on the market of such use rights must have meant that new categories of relatively affordable goods began to appear in the seventeenth century and that new classes of individuals began to find creating a waqf to be within their means. (Ghazaleh, 2011, p. 5) 
Such pyramids of waqf on waqf on waqf were seemingly frequent practice, but they were not consistent with the basics of the classic waqf law.

If fundamental inconsistencies occur, jurists should reconsider the law to find out whether that is still grounded on a common understanding of the "functioning" of the world. With respect to the awqā $f$ law in service economies, the concept of acceptable waqf assets may need an adjustment. For example, there are many forms of usufructs that could be made into waqf if recognized by contemporary fiqh (and national awqāf laws), and financial rights resulting from protected intellectual property (such as copyrights or patents) are not adequately covered in fiqh and $a w q \bar{a} f$ laws (Kahf, 1999).

In summary, various strategies can be applied to broaden the base for the financing of social expenditures through a revitalized and strengthened awqā $f$ system. However, more options do not automatically generate more funds for the $a w q \bar{a} f$ development if people are not willing to use them. The experience of

\section{References}

Abdel-Mohsin, M.I. (Ed.). (2016). Financing the Development of Old Waqf Properties: Classical Principles and Innovative Practices around the World. New York: Palgrave Macmillan.

Ahmad, A.U.F., \& Karim, M.F. (2017). Issues Deterring the Continued Growth of Awqaf in Bangladesh: The Way Forward to Its Development and Widening the Scope of Its Benefits. In N. Alam \& S. A. R. Rizvi (Eds.), Islamic Economies: Stability, Markets and Endowments (pp. 79-98). New York: Palgrave Macmillan.

Arshad, R., Zain, N.M., Urus, S.T., \& Chakir, A. (2018). Modelling Maqasid Waqf Performance Measures in Waqf Institutions. Global Journal Al Thaqafah (GJAT), Special Issue, 157-169.

Cizakca, M. (1998). Awqaf in History and Its Implications for Modern Islamic Economies. Islamic Economic Studies, 6(1), 43-70.

Ghazaleh, P. (2011). Introduction: Pious Foundations From Here to Eternity? In: P. Ghazaleh (Ed.), Held in Trust: Waqf in the Islamic World (pp. 1-22). Cairo: American University in Cairo Press.

Hanna, N. (2011). Guild Waqf: Between Religious Law and Common Law. In P. Ghazaleh (Ed.), Held in
Malaysia illustrates what complementary actions may be required:

The great attraction of the waqf to devout Muslims is the theological basis of the instrument. However, modern Malaysia is demonstrating that the trust as a secular instrument is a more effective means of achieving the aims of individual devout Muslims who do not want to attract the intrusive regulation of the state that a waqf necessitates. This is a lesson which is likely to have wider application. (Stibbard et al., 2012, p. 810)

The comparable ease to participate in a cash waqf may even have supported the tendency to create trusts instead of awqāf: The contribution to a cash waqf may be sufficient to attain the religious rewards, and a secular trust can serve all the mundane motives for setting up a foundation. If this is a widespread practice, then there is an urgent need to reconsider the whole $a w q \bar{a} f$ system and its current management in the context of a secular legal system that also supports philanthropy and care for the own family.

Trust: Waqf in the Islamic World (pp. 135-153). Cairo: American University in Cairo Press.

Hoexter, M. (2002). The Waqf and the Public Sphere. In M. Hoexter, S. N. Eisenstadt, N. Levtzion (Eds.), The Public Sphere in Muslim Societies (pp. 119-138). New York: State University of New York Press.

Kahf, Monzer (1999, October). Towards the Revival of Awqaf: A few Fiqhi Issues to reconsider. Paper presented at the Harvard forum on Islamic finance and economics, Harvard University, U.S.A. Retrieved from: http://monzer.kahf.com/papers/english/ FIQHI_ ISSUES_FOR_REVIVAL_OF_waqf.pdf

Obaidullah, M. (2013). A waqf Development and Management. Jeddah: IRTI.

Rashid, S.K. (2018). Potential of Waqf in Contemporary World. Journal of King Abdulaziz University: Islamic Economics, 31(2), 53-69.

Stibbard, P., Russell, D., \& Bromley, B. (2012). Understanding the Waqf in the World of the Trust. Trusts \& Trustees, 18(8), 785-810.

World Bank (2017). Mobilizing Islamic Finance for Infrastructure Public-Private Partnerships (Report 2017). Washington: Author. 
Volker Nienhaus received his doctorate and post-doctorate in economics from the University of Bochum (Germany). He was full professor of economics at the German universities of Trier (1989-1990) and Bochum (1990-2004) and President of the University of Marburg (2004-2010). He holds an honorary professorship of the University of Bochum and is Visiting Professor at the University of Reading, UK (since 2010). He was Visiting Professor at the University of Malaya (2010/11) and the Qatar Faculty of Islamic Studies (2011). He served as consultant to the Islamic Financial Services Board and in several academic advisory committees and boards, including the German Federal Ministry of Economic Co-operation and Development (1998-2008) and the Governing Council of INCEIF (International Centre for Education in Islamic Finance) in Kuala Lumpur (since 2006) where he also became Adjunct Professor (since 2012). He is member of the Supervisory Board of FWU AG in Munich (since 2013), an internationally operating family takäful provider. His interest in Islamic economics and finance dates back to the late 1970s.

E-mail: volker.nienhaus@gmx.net 


\title{
الأوقاف: الإنفاق الاجتماعي واستر اتيجية التنمية والتمويل
}

\author{
فولكرنيانهاوس \\ الرئيس السابق بجامعاة مارببغ ألمانيا وأستاذ زائر بجامعاة ريلدينج ، المملكة المتحسدة \\ المستخلص. إن إحياء وتطوير الأوقاف القديمة يمكن أن يُوَلِّد إيرادات معتبرة لتمويل النفقات \\ الاجتماعية (إلا أن هذه الموارد قد تكون أقل من التقديرات المتفائلة [التي وردت في الكثير من

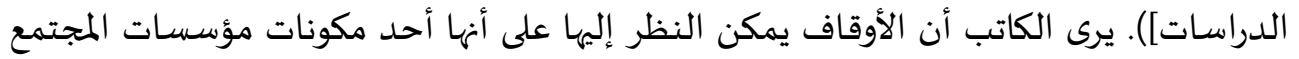

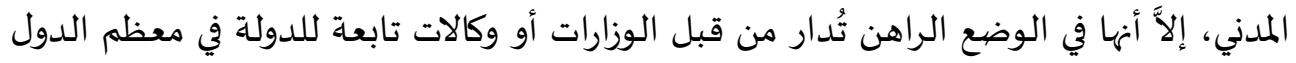

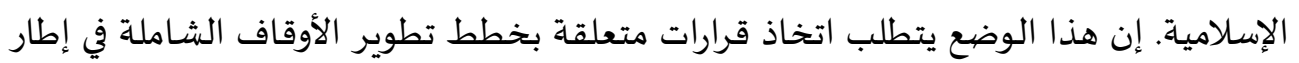

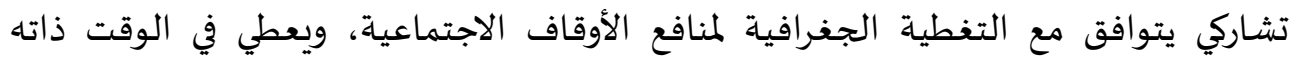

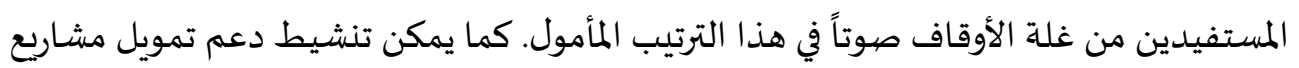

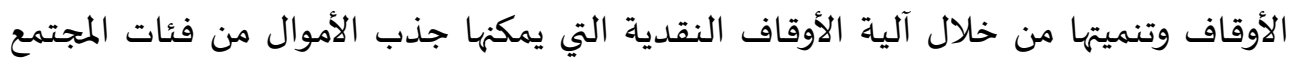

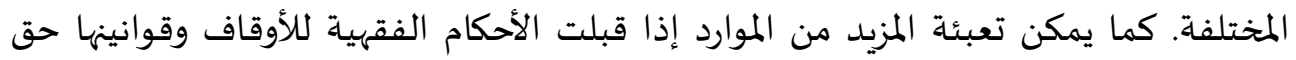 \\ الانتفاع بالحقوق المعنوية والمالية كأساس للوقف. \\ الكلمات الدَّالة: استراتيجية تطوير الأوقاف، خطط الرفاه الاجتماعي، وقف الحقوق. \\ تصنيف K22
}

